\title{
SANKSI HUKUM TIDAK TERPENUHINYA PENDAPATAN ASLI DAERAH (PAD) DARI PAJAK REKLAME
}

\author{
Ahmad Fathoni*, Abdul Basid** \\ Fakultas Hukum Universitas Gresik \\ * Mahasiswa Fakultas Hukum Universitas Gresik \\ **Dosen Fakultas Hukum Universitas Gresik \\ Email : \\ Abdulbasid6971@gmail.com \\ thoni111222@gmail.com
}

\begin{abstract}
ABSTRAK
Dalam rangka pembiayaan pembangunan, peranan dan potensi sektor perpajakan sangat besar artinya, terutama untuk menunjang keberhasilan pembangunan daerah dan pembangunan nasional. Sumber pembiayaan Negara antar lain dari pajak dan kekayaan alam. Tujuan penelitian ini untuk mengetahui kontribusi pajak reklame dan evaluasi manakala target pajak reklame tidak terpenuhi. Skripsi ini ditulis dengan pendekatan yuridis normative. Penyelenggaraan reklame kabupaten gresik di atur dalam Peraturan Bupati Gresik Nomor 9 Tahun 2016 tentang Penyelenggaraan Reklame. Kontribusi pajak reklame terhadap pajak daerah sebesar $0.58 \%$ dan kontribusi pajak reklame terhadap pendapatan asli daerah sebesar $0.11 \%$. Evaluasi dilakukan setiap 3 bulan dan 6 bulan serta dilakukan saat target pajak reklame tidak terpenuhi. Evaluasi dilakukan pada setiap pokja yang terkait dengan penyelenggaraan reklame. Kepada pihak yang terkait supaya lebih menegaskan sanksi terhadap pelanggaran penyelenggaraan reklame.
\end{abstract}

Kata Kunci : Pajak Reklame, Pendapatan Asli Daerah, Sanksi Hukum

\section{ABSTRACK}

In the framework of financing development, the role and potential of the taxation sector is very significant, especially to support the success of regional development and national development. Other state funding sources include taxes and natural wealth. The purpose of this study is to determine the advertisement tax contribution and evaluation when the advertisement tax target is not met. This thesis was written with a normative juridical approach. The implementation of the Gresik regency bill is regulated in the Gresik Regent Regulation Number 9 of 2016 concerning the Implementation of Advertisement. The advertisement tax contribution to local taxes is $0.58 \%$ and the advertisement tax contribution to local revenue is $0.11 \%$. Evaluation is carried out every 3 months and 6 months and is carried out when the advertisement tax target is not met. Evaluation is carried out at each working group related to the implementation of billboards. To 
the parties concerned so as to further emphasize sanctions against violations of the implementation of billboards.

Keywords: Advertisement Tax, Regional Original Income, Legal Sanctions

\section{PENDAHULUAN}

Berdasarkan Undang-undang Dasar Negara Republik Indonesia Tahun 1945 Pasal 1 Angka (3). "Negara Indonesia adalah negara hukum". Hal ini dapat kita lihat dari banyak sekali Undang-Undang yang berlaku di Indonesia. Semua Undang-Undang tersebut berfungsi untuk mengatur kehidupan masyarakat Indonesia. Sehingga segala tingkah laku masyarakat yang berada di kawasan Republik Indonesia dapat diawasi oleh hukum yang berlaku di Indonesia. Kita sebagai warga Negara Indonesia yang baik, harus mematuhi segala macam peraturan dan UndangUndang yang berlaku di Indonesia.

Hukum tidak dapat
dipisahkan dari kehidupan suatu
masyarakat. Karena di dalam suatu
kehidupan masyarakat pasti ada
suatu bentuk peraturan yang berlaku
di masyarakat tersebut yang
mengatur tata cara bermasyarakat.
Selain itu, kita tentu tidak dapat
membayangkan bagaimana jadinya
jika kehidupan masyarakat tidak ada
hukum yang berlaku.

Pembangunan nasional akan
mampu terealisasi dengan baik
manakala sumber pembiayaan
pembangunan dapat tercukupi,
sehingga untuk
pembangunan nasional diperlukan
dana dalam jumlah yang besar.
"Sumber pembiayaan Negara antar

lain dari pajak dan kekayaan alam yang meliputi sektor pertambangan, kehutanan yang merupakan sumber yang tidak dapat diperbaharui dan mempunyai akibat langsung bagi generasi mendatang. Untuk itulah maka sektor aman dalam pembiayaan pembangunan." 1

Sebagai Negara berkembang, Indonesia memiliki fungsi dalam mengusahakan kesejahteraan dan kemakmuran rakyatnya. Agar dapat mewujudkan hal tersebut, segala potensi dan sumber daya yang ada harus dialokasikan secara efektif dan efisien secara terus menerus yang disebut dengan pembangunan nasional bukan hanya menjadi tanggung jawab dari pemerintah pusat saja, tetapi pemerintah daerah juga memiliki peran yang sama untuk keberhasilan tersebut. Hal ini terlihat dalam pemerintah pusat melalui otonomi kepada pemerintah daerah untuk mengelola daerahnya sendiri.

Munculnya otonomi daerah menyebabkan terjadinya pergeseran paradigma dari sistem pemerintah bercorak sentralisasi mengarah kepada sistem pemerintahan yang desentralisasi, yaitu dengan memberikan keleluasaan terhadap

\footnotetext{
1 Wiratni Ahmad, "Pajak Tanah Sebagai Upaya Sinkronisasi Pajak Tanah dan Kebijaksanaan Pertanahan di Indonesia", Disertasi, Jakarta, 1996, h.7.
} 
daerah dalam mewujudkan daerah otonom yang bertanggung jawab, untuk mengatur dan mengurus kepentingan masyarakat sesuai dengan kondisi dan potensi yang dimiliki oleh wilayah tersebut. Pemberian otonomi daerah juga pada dasarnya bertujuan untuk meningkatkan daya guna dan hasil guna penyelenggaraan pemerintah daerah, terutama dalam pelaksanaan pembangunan dan pelayanan masyarkat serta peningkatan pembinaan kesatuan politik dan kesatuan bangsa.

Dalam rangka pembiayaan pembangunan, peranan dan potensi sektor perpajakan sangat besar artinya, terutama untuk menunjang keberhasilan pembangunan daerah dan pembangunan nasional. Masalah umum yang dihadapi oleh pemerintah di Indonesia adalah sumber pendapatan daerah. Dimana sumber pendapatan daerah, selain berusaha untuk memenuhi keperluan biaya rutin, pemerintah juga berkewajiban untuk melaksanakan pembangunan sesuai dengan kemampuan masing-masing daerah.

Persyaratan pertama yang paling jelas untuk suatu sumber pendapatan tersebut harus menghasilkan pendapatan yang besar dalam kaitannya dengan seluruh atau sebagian biaya pelayanan yang akan dikeluarkan pemerintah. Seringkali dalam undang-undang mempunyai banyak jenis pajak yang dijadikan sumber penerimaan, tetapi tidak ada yang menghasilkan lebih dari persentasi yang kecil dari anggaran pengeluarannya
Pajak merupakan salah satu sumber pemasukan kas Negara yang digunakan untuk pembangunan dengan tujuan akhir kesejahteraan dan kemakmuran rakyat. Oleh karena itu, sektor pajak memegang peranan penting dalam perkembangan kesejahteraan bangsa. Namun, tidak bisa dipungkiri bahwa sulitnya Negara melakukan pemungutan pajak karena banyaknya wajib pajak yang tidak patuh dalam membayar pajak merupakan suatu tantangan tersendiri.

Sebagai salah satu sumber penerimaan yang memiliki potensi cukup besar, pajak daerah seharusnya mendapatkan perhatian khusus dalam pengelolahannya. Hal ini ditunjang oleh banyaknya penggunaan jasa yang disediakan oleh pemerintah kepada orang pribadi maupun pihak swasta, sehingga pemerintah memiliki peluang dalam mengoptimalisasikan pemungutan pajak daerah secara maksimal.

Sesuai Dengan Isi Bab II Undang Undang Nomor 28 Tahun 2009 Tentang Pendapatan Daerah Retribusi Daerah (PDRD) pada ayat II dijelaskan jeni jenis pajak kabupaten/kota yang terdiri atas: pajak hotel, pajak restoran, pajak hiburan, pajak reklame, pajak penerangan jalan, pajak mineral bukan logam dan batuan, pajak parkir, pajak air tanah, pajak sarang burung wallet, pajak bumi dan bangunan perdesaan dan perkotaan dan pajak bea perolehan hak atas tanah dan bangunan.

Banyak media yang menjadi pilihan untuk menawarkan produk- 
produk baik berupa barang atau jasa. Seperti media reklame, media televisi, media radio, dll. Salah satu media yang diminati oleh para pengusaha adalah media reklame. Karena reklame disekitar jalan bisa dengan mudah dilihat oleh masyarakat, banyak jenis reklame salah satunya adalah reklame papan/billboard, reklame kain, reklame sticker, megatron dan lainlain.

Kabupaten Gresik sudah di kenal sejak abad ke -11. Ketika tumbuh menjadi pusat perdagangan tidak saja antar pulau, tetapi sudah meluas ke berbagai belahan negara. Sebagai kota bandar, Gresik banyak dikunjungi pedagang China, Arab, Gujarat dll. Seiring perkembangan zaman, Kabupaten Gresik semakin berkembang, terutama dalam hal perekonomian. Berawal dari pusat perdagangan, kini Kabupaten Gresik berkembang menjadi kota industri.

Gresik dikenal sebagai kota industri karena terdapat kurang lebih 1400 industri di Gresik yang terdiri dari indstri berskala keil dan besar. Dari banyaknya industri di Gresik tersebut, banyak media - media yang digunakan untuk mempromosikan produk atau jasa dari masing masing industri tersebut. Media/reklame yang menjadi ajang promosi terdiri dari banyak jenis yang terpasang di setiap sudut jalan.

$\begin{array}{lr}\text { Reklame } & \text { memberikan } \\ \text { sumbangan besar } & \text { terhadap }\end{array}$

\footnotetext{
${ }^{2}$ Kabupaten Gresik, Wikipedia ( Online ), 15 November 2018, h <https://id.wikipedia.org/wiki/Kabupten _Gresik>
}

Pendapatan Asli Daerah di Kabupaten Gresik karena banyaknya pelaku usaha yang menawarkan barang dan jasa mereka melalui reklame. Akan Tetapi seiring berjalannya waktu, banyak pelaku usaha yang kurang mematuhi peraturan yang ada. Sehingga banyak ditemukan reklame bodong di Kabupaten Gresik. Dan kurang tegasnya sanksi hukum atas pelanggaran peraturan tentang penyelenggaraan reklame tersebut membuat para pelaku usaha kurang mematuhi peraturan tersebut. Dengan adanya peristiwa tersebut, secara tidak langsung hal tersebut dapat mengurangi Pendapatan Asli Daerah di Kabupaten Gresik dan secara tidak langsung juga merugikan pemerintah daerah. Dan penelitian ini dilakukan untuk mengetahui kontribusi pajak reklame dan sanksi hukum apabila pajak reklame tidak mencapai target yang sudah ditentukan.

\section{METODE PENELITIAN}

Jenis penelitian yang dilakukan oleh peneliti adalah penelitian Yuridis Normatif. Penelitan hukum yuridis normative adalah penelitian yang dilakukan dengan cara meneliti bahan pustaka atau data sekunder sebagai bahan dasar untuk diteliti dengan cara mengadakan penelusuran terhadap peraturan - peraturan dan literature literature yang berkaitan dengan permasalahan yang diteliti. Dalam penelitian ini, peneliti melakukan penelitian tentang bagaimana hukum digunakan untuk dijadikan isntrumen penegakan dan penerapan mekanisme pengawasan dan penindakan terhadap 
penyelenggaraan reklame di Kabupaten Gresik. Dalam penelitian ini, peneliti menggunakan pendekatan penelitian perundang undangan. Dalam penlitian ini, peneliti mengkaji Undang - Undang Nomor 28 tahun 2009 tentang Pajak Daerah dan Retribusi Daerah dan Peraturan Bupati Gresik Nomor 9 tahun 2016 tentang penyelenggaraan reklame.

\section{PEMBAHASAN}

\section{Pendapatan Asli Daerah}

\begin{tabular}{cll}
\multicolumn{2}{c}{ Menurut } & \multicolumn{2}{l}{ Undang-Undang } \\
No.32 Tahun & 2004 tentang
\end{tabular} pemerintahan daerah menyebutkan bahwa pendapatan daerah yaitu semua hak daerah yang diakui sebagai penambah nilai kekayaan bersih dalam periode anggaran tertentu. Sedangkan menurut Undang-Undang No.33 Tahun 2004 tentang Perimbangan Keuangan Antara Pusat dan Daerah Pasal 1 angka 18 menyebutkan bahwa "Pendapatan asli daerah, selanjutnya disebut PAD adalah pendapatan yang diperoleh daerah yang dipungut berdasarkan peraturan daerah sesuai dengan peraturan perundangundangan".

Undang-Undang No.28 Tahun 2009 juga menyebutkan tentang pengertian pendapatan asli daerah yaitu sumber keuangan daerah yang digali dari wilayah daerah yang bersangkutan yang terdiri dari hasil pajak daerah, hasil retribusi daerah, hasil pengelolahan kekayaan daerah yang dipisahkan dan lain-lain pendapatan asli daerah yang sah.
Menurut Undang-Undang RI No.32 Tahun 2004 sumber-sumber pendapatan asli daerah, yaitu: ${ }^{3}$

1.

endapatan Asli Daerah (PAD) terdiri dari:

a. asil Pajak Daerah,

b. asil retribusi

c. asil perusahaan milik daerah dan hasil pengelolaan kekayaan daerah yang dipisahkan.

d.

ain-lain pendapatan daerah yang sah berupa jasa giro, penjualan aset tetap daerah, pendapatan bunga, keuntungan selisih nilai rupiah terhadap mata uang asing, komisi, potongan, dan bentuk lain sebagai akibat dari penjualan atau pengadaan barang dan jasa oleh daerah.

2.

ana perimbangan

3.

ain-lain pendapatan daerah yang sah

\section{Pajak Daerah}

Menurut S.I. Djajadinigrat: "Pajak sebagai suatu kewajiban menyerahkan sebagian dari kekayaan ke kas negara yang disebabkan suatu keadaan, kejadian, dan perbuatan yang memberikan kedudukan tertentu, tetapi bukan sebagai

\footnotetext{
${ }^{3}$ Prasetyo, Hindarto, "Kontribusi Pajak Reklame Terhadap Pendapatan Asli Daerah Kabupaten Kudus Tahun 2000-2004", Skripsi,Semarang 2006
} 
hukuman, menurut peraturan yang ditetapkan pemerintah serta dapat dipaksakan, tetapi tidak ada jasa timba balik dari negara secara langsung, untuk memelihara kesejahteraan secara umum."4

Menurut Mardiasmo mengatakan bahwa "Pajak Daerah adalah pajak yang dipungut daerah berdasarkan peraturan yang ditetapkan oleh daerah (melalui Peraturan daerah) untuk kepentingan pembiayaan rumah tangga Pemerintah Daerah". Berdasarkan Undang-Undang No. 28 Tahun 2009 jenis-jenis pajak daerah terdiri dari:

1. Jenis Pajak Propinsi
a. Pajak kendaraan Bermotor;
b. Pajak Balik Nama Kendaraan Bermotor;
c. Pajak Bahan Bakar Kendaraan Bermotor;
d. Pajak Air Permukaan; dan
e. Pajak Rokok.

2. Jenis Pajak Kabupaten atau Kota
a. Pajak Hotel
b. Pajak Restoran
c. Pajak Hiburan
d. Pajak Reklame
e. Pajak Penerangan Jalan
f. Pajak Mineral Bukan Logam dan Batuan
g. Pajak Parkir
h. Pajak Air Tanah
i. Pajak Sarang Burung Walet
j. Pajak Bumi dan Bangunan Perdesaan dan Perkotaan
k. Bea Perolehan Hak atas Tanah dan Bangunan.

\footnotetext{
${ }^{4}$ Puspitasari, Elfayang Rizki."Analisis Efektivitas, Efisiensi, Dan Kontribusi Pajak Dan Retribusi Daerah Terhadap PAD Kabupaten Blora Tahun 2009. 2013”, Skripsi, Semarang 2014.
}

Peraturan daerah tentang pajak berisi antara lain sebagai berikut :

1. Pajak Ditetapkan dengan Peraturan Daerah

2. Peraturan daerah tentang pajak tidak dapat berlaku surut

3. Peraturan Daerah tentang pajak sekurang-kurangnya mengatur ketentuan mengenai :

a. Nama, objek dan subjek pajak

b. Dasar pengenaan, tarif dan cara penghitungan pajak

c. Wilayah pemungutan

d. Masa pajak

e. Penetapan

f. Tata cara pembayaran dan penagihan

g. Kadaluwarsa

h. Sanksi administrasi

i. Tanggal mulai berlakunya

4. Peraturan Daerah tentang pajak dapat mengatur ketentuan mengenai:

a. Pemberian pengurangan, keringanan, dan pembebasan dalam hal-hal tertentu atas pokok pajak dan/atau sanksinya

b. Tata cara pengghapusan piutang pajak yang kadaluarsa

c. Asas timbal balik

5. Peraturan Daerah tentang objek, subjek dan dasar pengenaan pajak harus terlebih dahulu disosialisasikan dengan masyarakat sebelum ditetapkan.

6. Ketentuan mengenai tata cara mekanisme pelaksanaan sosialisasi Peraturan daerah ditetapkan oleh Kepala Daerah.

Peraturan Daerah disampaikan kepada pemerintah paling lama 15 (lima belas) hari setelah ditetapkan. 
Apabila Peraturan Daerah tersebut bertentangan dengan kepentingan umum dan/atau peraturan perundangundangan yang lebih tinggi, maka pemerintah dapat membatalkan Peraturan Daerah tersebut. Pembatalan dilakukan paling lama 1 (satu) bulan sejak diterimanya Peraturan Daerah yang dimaksud.

\section{Pajak Reklame}

Reklame adalah benda, alat, perbuatan, atau media yang bentuk dan corak ragamnya dirancang untuk tujuan komersial memperkenalkan, menganjurkan, mempromosikan, atau untuk menarik perhatian umum terhadap barang, jasa, orang, atau badan, yang dapat dilihat, dibaca, didengar, dirasakan, dan/atau dinikmati oleh umum kecuali yang dilakuakan oleh pemerintah. Reklame adalah pemberitahuan kepada umum tentang barang dagangan dengan kata-kata yang menarik, gambar, dsb supaya laku. ${ }^{5}$

Pajak Reklame adalah yang selanjutnya disebut Pajak adalah Pajak atas penyelenggaraan reklame. Penyelenggaraan reklame adalah orang atau badan yang menyelenggarakan reklame, baik untuk dan atas namanya sendiri atau untuk dan atas nama pihak lain yang menjadi tanggungannya. ${ }^{6}$

Pengenaan pajak reklame tidak mutlak ada pada seluruh daerah kabupaten atau daerah kota seluruh Indonesia. Hal ini berkaitan dengan

\footnotetext{
${ }^{5}$ Kamus Pusat Bahasa, Kamus Bahasa Indonesia. Departemen Pendidikan Nasional, Jakarta 2008.h.579

${ }^{6}$ Marihot P Siahaan. Pajak Daerah dan Retribusi Daerah PT. Raja Grafindo, Jakarta 2006.h.66.
}

kewenangan yang diberikan kepada pemerintah Kabupaten/Kota untuk mengenakan atau tidak mengenakan suatu jenis pajak Kabupaten/Kota. Untuk dapat dipungut pada suatu daerah Kabupaten/Kota, pemerintah daerah harus terlebih dahulu menerbitkan peraturan daerah tentang pajak reklame yang akan menjadi landasan hukum operasional dalam teknis pelaksanaan pengenaan dan pemungutan pajak reklame di daerah Kabupaten atau Kota yang bersangkutan.

Tarif Pajak Reklame dikenakan atas objek reklame adalah paling tinggi sebesar dua puluh lima persen dari nilai sewa reklame dan ditetapkan dengan peraturan daerah kabupaten/kota yang bersangkutan. Pemungutan Pajak menurut UndangUndang Nomor 28 Tahun 2009 adalah suatu rangkaian kegiatan mulai dari penghimpunan data objek dan subjek pajak atau retribusi, penentuan besarnya pajak atau retribusi yang terutang sampai kegiatan penagihan pajak atau retribusi kepada wajib pajak atau retribusi serta pengawasan penyetorannya. Dalam pemungutan pajak secara umum ada beberapa sistem yang digunakan, mengemukakan sistem pemungutan pajak :

- Official Assesment System adalah suatu system pemungutan yang memberikan wewenang kepada pemerintah (fiskus) untuk menentukan besarnya pajak yang terhutang oleh wajib pajak

- Self assessment System, suatu system pajak memberikan wewenang kepada wajib pajak 
untuk menentukan sendiri besarnya pajak yang terutang.

\begin{tabular}{llr}
\multicolumn{1}{c}{ Dengan } & \multicolumn{2}{c}{ menigkatnya } \\
pelaksanaan & pembangunan dan \\
pertumbuhan & perekonomian yang
\end{tabular}
ditunjang dengan sarana dan prasarana yang semakin memadai, diperlukan upaya menggali dan meningkatkan sumber pendapatan asli daerah diantaranya pajak daerah yang merupakan sumber pendapatan yang penting guna membiayai penyelenggaraan pemerintah dan pembangunan daerah untuk mendukung pelaksanaan otonomi daerah yang nyata, luas, dinamis dan bertanggung jawab sebagaimana diamanatkan dalam undang-undang nomor 32 tahun 2004 tentang pemerintah daerah. Berdasarkan undang-undang nomor 28 tahun 2009 tentang pajak daerah dan retribusi daerah telah ditetapkan jenis-jenis pajak daerah dan retribusi daerah yang menjadi kewenangan pemerintah daerah Kabupaten/Kota, untuk itu pemerintah daerah melakukan pemungutan Pajak sebagai sumber pendapatan keuangan daerah, termasuk di dalamnya pajak reklame.

Selanjutnya dalam Peraturan Bupati Kabupaten Gresik No 9 Tahun 2016 tentang penyelenggaraaan reklame menjelaskan bahwa Reklame adalah benda, alat atau perbuatan atau media yang menurut bentuk dan cara ragamnya untuk tujuan komersial, dipergunakan untuk memperkenalkan, menganjurkan atau memujikan suatu barang, jasa atau orang yang ditempatkan atau yang dapat dilihat, dibaca dan/atau dengan dari suatu tempat oleh umum, kecuali yang dilakukan oleh Pemerintah.

Reklame terbagi menjadi beberapa jenis, adapun jenis - jenis reklame tersebut adalah:

a. Reklame Tetap Terbatas

b. Reklame permanen

c. Reklame insidentil

d. Reklame Megatron

e. Reklame Papan/Bilboard

f. Reklame Baliho

g. Reklame Kain

h. Reklame Melekat (stiker)

i. Reklame Selebaran

j. Reklame Berjalan/Kendaraan

k. Reklame Udara

1. Reklame Apung

m. Reklame Slide/Film

n. Reklame Peragaan

Pemegang izin atau Penyelenggara Reklame adalah orang pribadi atau badan yang menyelenggarakan reklame baik untuk dan atas namanya sendiri atau untuk pihak lain yang menjadi tanggungannya.

Penyelenggaraan Reklame di Kabupaten Gresik diklasifikasikan menjadi 3 sesuai dengan BAB III pasal 3, yaitu :

a. Reklame Insidentil

Jenis Reklame yang masuk dalam klasifikasi Insidentil, terdiri dari:

1. Reklame Baliho

2. Reklame kain,

3. Reklame Melekat/Stiker

4. Reklame Selebaran

5. Reklame Udara

6. Reklame Apung.

7. Reklame Film/Slide.

8. Reklame peragaan.

b. Reklame Permanen 
Penyelenggaraan

Reklame Permanen sebagaimana dimaksud dalam Pasal 3 adalah penyelenggaraan reklame sebagai berikut :

1) Reklame Tempel yang diselenggarakan di lokasi persil

2) Reklame Tiang dengan luas bidang kurang dari atau sama dengan $2 \mathrm{~m} 2$ (dua meter persegi) yang diselenggarakan di lokasi persil

3) Reklame yang terletak diatas/berdiri/dengan

konstruksi pada bangunan dengan luas bidang lebih kecil atau sama dengan $8 \mathrm{~m} 2$ (delapan meter persegi)

4) Reklame Berjalan

c. Reklame Tetap Terbatas.

Penyelenggaraan
Reklame Tetap Terbatas
sebagaimana dimaksud dalam
Pasal 3 adalah penyelenggaraan
reklame sebagai berikut:

1) Reklame Tiang dengan luas bidang lebih besar dari $2 \mathrm{~m} 2$ (dua meter persegi) yang diselenggarakan di lokasi persil

2) Reklame Tiang di luar persil

3) Reklame yang terletak diatas/berdiri/dengan

konstruksi pada bangunan dengan luas bidang reklame lebih besar dari $8 \quad \mathrm{~m} 2$ (delapan meter persegi).

Pada pasal 6 peraturan Bupati Gresik No 9 Tahun 2016 tentang penyelenggaraan Reklame menjelaskan tentang perizinan penyelenggaraan Reklame. Dalam pasal 6 tersebut disebutkan Setiap orang pribadi atau Badan yang akan menyelenggarakan reklame di Daerah, wajib memperoleh izin tertulis dari Bupati atau pejabat yang ditunjuk. Reklame yang tidak diwajibkan memiliki izin sebagaimana dimaksud adalah :

a. Reklame melalui televisi, radio, warta harian, warta mingguan, warta bulanan, dan sejenisnya;

b. Reklame yang semata-mata memuat nama tempat ibadah dan tempat panti asuhan;

c. Reklame yang hanya mencantumkan nama pengenal usaha atau profesi yang dipasang melekat pada bangunan tempat usaha atau profesi dan diselenggarakan sesuai dengan ketentuan yang mengatur nama pengenal usaha atau profesi tersebut dengan luas yang tidak melebihi $1 \mathrm{~m}^{2}$ (satu meter persegi);

d. Reklame yang diselenggarakan oleh Pemerintah, Pemerintah Provinsi dan Pemerintah Daerah serta Instansi lainnya, kecuali yang dikerjasamakan dengan pihak ketiga (sponsor);

e. Reklame yang diperuntukkan bagi keperluan pemilihan calon Kepala Desa, anggota legislatif, Bupati dan Wakil Bupati, Gubernur, dan Wakil Gubernur, Presiden dan wakil Presiden, serta atribut Partai dengan ketentuan luasnya tidak lebih dari $2 \mathrm{~m}^{2}$ (dua meter persegi).

Selanjutnya pengawasan penyelenggaraan reklame di atur dalam Peraturan Bupati No 9 Tahun 2016 tentang Penyelenggaraan 
Reklame pasal 36. Pengawasan penyelenggaraan reklame dilakukan oleh Tim Pokja Pengawasan Reklame. Tim Pokja Pengawasan Reklame diketuai oleh Sekretaris Daerah dan dibentuk berdasarkan Keputusan Bupati.

Tim Pokja Pengawasan Reklame sebagaimana dimaksud memiliki tugas untuk melakukan evaluasi dan pengawasan terhadap pelaksanaan penyelenggaraan reklame. Tim Pokja Pengawasan Reklame beranggotakan:

a. Badan Penanaman Modal dan Perizinan;

b. Dinas Pekerjaan Umum;

c. DPPKAD;

d. Badan Lingkungan Hidup

e. Dinas Perhubungan;

f. Dinas Kebudayaan,Pariwisata, Pemuda,dan Olah Raga;

g. Satuan Polisi Pamong Praja.

Dalam Peraturan Bupati Gresik No 9 Tahun 2016 tentang Penyelenggaraan Reklame Bab IX tentang sanksi administrasi. Pada pasal 45 dijelaskan bahwa Badan Penanaman modal dan perizinan dapat menghentikan pemasangan reklame baik untuk sementara maupun bersifat tetap apabila :

a. Konstruksi yang dikerjakan tidak sesuai dengan syarat teknis yang diizinkan

b. Belum memiliki izin tertulis dari Bupati atau pejabat yang ditunjuk

c. Merubah bentuk dan/atau materi pada reklame yang telah diizinkan tanpa persetujuan Pejabat yang menandatangani izin tersebut d. Menempatkan reklame pada titik pemasangan diluar tempat yang disetujui sesuai izin yang diberikan

e. Penanggungjawab izin penyelenggaraan reklame berpindah tangan kepada pihak lain tanpa persetujuan pejabat yang menandatangani izin secara tertulis.

Objek Pajak Reklame adalah semua penyelenggaraan reklame yang meliputi:

a. Reklame papan/billboard antara lain papan merk, ground sign, neon sign/neon boks, bando jalan dan baliho;

b. Reklame megatron/videotron/ large electronic display (LED);

c. Reklame kain ;

d. Reklame melekat ;

e. Reklame selebaran;

f. Reklame berjalan (termasuk pada kendaraan);

g. Reklame udara (balon udara);

h. Reklame suara;

i. Reklame apung;

j. Reklame film/slide;

k. Reklame peragaan;

Tidak termasuk obyek pajak reklame adalah :

a. Penyelenggaraan reklame melalui internet, televisi, radio, warta harian, warta bulanan dan sejenisnya;

b. Label/merek produk yang melekat pada barang yang diperdagangkan, yang berfungsi untuk membedakan dari produk sejenis lainnya;

c. Nama pengenal usaha atau profesi yang dipasang melekat pada bangunan tempat usaha atau 
profesi diselenggarakan sesuai dengan ketentuan yang mengatur nama pengenal usaha atau profesi tersebut;

d. Reklame yang diselenggarakan oleh Pemerintah, Pemerintah Provinsi dan Pemerintah Daerah;

e. penyelenggaraan Reklame yang dipergunakan untuk keperluan amal, sosial, dan politik.

Subjek pajak reklame dijelaskan dalam pasal 33 Peraturan Daerah No.2 Tahun 2011 tentang pajak daerah. Adapun Subjek pajak reklame tersebut adalah :

1. Subjek pajak reklame adalah orang pribadi atau Badan yang menggunakan Reklame.

2. Wajib pajak reklame adalah orang pribadi atau badan yang menyelenggarakan reklame.

3. Dalam hal Reklame diselenggarakan sendiri secara langsung oleh orang pribadi atau Badan, Wajib Pajak Reklame adalah orang pribadi atau Badan tersebut.

4. Dalam hal reklame diselenggarakan melalui pihak ketiga, pihak ketiga tersebut menjadi Wajib Pajak Reklame.

Selanjutnya, dalam pasal 34 menjelaskan tentang dasar pengenaan, tarif dan cara perhitungan pajak reklame yaitu:

1. Dasar pengenaan Pajak Reklame adalah Nilai Sewa Reklame.

2. Nilai Sewa Reklame sebagaimana dimaksud pada ayat

(1) dihitung sebagai berikut :

a. Dalam hal diselenggarakan oleh orang pribadi atau badan yang memanfaatakan reklame untuk kepentingan sendiri, Nilai Sewa Reklame dihitung berdasarkan biaya pemasangan reklame, biaya pemeliharaan reklame, lama pemasangan reklame, nilai strategis lokasi dan jenis reklame.

b. Dalam hal Reklame diselenggarakan oleh pihak ketiga, Nilai Sewa Reklame sebagaimana dimaksud pada ayat (1) ditentukan berdasarkan jumlah pembayaran untuk suatu masa pajak/ masa penyelenggaraan reklame dengan memperhatikan faktor-faktor sebagaimana dimaksud huruf a.

3. Biaya pemasangan reklame termasuk biaya pembuatan dan biaya pemeliharaan sebagaimana dimaksud pada ayat (2) huruf a., didasarkan pada standar biaya yang ditetapkan secara periodik oleh Bupati.

4. Lama pemasangan atau jangka waktu penyelenggaraan reklame adalah harian, mingguan, bulanan, dan tahunan.

5. Nilai Sewa Reklame (NSR) sebagaimana dimaksud pada ayat (2) dihitung dengan rumus sebagai berikut :

$\mathrm{NSR}=$

Biaya Pemasangan + pemeliharaan

Umur Ekonomis/LamaPemasangan + Nilai Strategis

6. Nilai Strategis sebagaimana dimaksud pada ayat ditentukan oleh faktor-faktor :

a) Guna lahan (potensi dari tempat/kawasan dalam 

mencapai
sasaran
pemasangan reklame)
b) Ukuran Reklame
c) Sudut pandang reklame
d) Kelas jalan
e) Harga titik / lokasi pemasangan reklame

7. Tata cara perhitungan Nilai Sewa Reklame sebagaimana dimaksud pada ayat (5) ditetapkan dengan Peraturan Bupati.

Pajak Reklame dipungut dengan sistem Official Assesment. Official Assesment System adalah suatu system pemungutan yang memberikan wewenang kepada pemerintah (fiskus) untuk menentukan besarnya pajak yang terhutang oleh wajib pajak. Tarif pajak reklame ditetapkan sebesar 25 $\%$ (dua puluh lima persen).

Selanjutnya, mekanisme penyelenggaraan reklame termuat dalam Peraturan Bupati kabupaten Gresik No.9 Tahun 2016 tentang penyelenggaraan reklame. Adapun ketentuan penyelenggaraan reklame berdasarkan Peraturan Bupati Gresik No.9 tahun 2016 tentag penyelenggaraan reklame pasal 18 yaitu:

a. Diselenggarakan dengan tidak menutup pandangan rambu, lampu pengatur, dan kamera lalu lintas;

b. Konstruksi reklame dapat dipertanggungjawabkan menurut persyaratan teknis;

c. Lampu reklame yang dipasang diarahkan ke bidang reklame sehingga tidak menyilaukan pandangan pemakai jalan; dan

d. Instalasi listrik yang dipasang harus memenuhi persyaratan teknis sehingga tidak membahayakan keselamatan umum.

Disetiap daerah, sudah tentu memiliki rancangan pembangunan daerah. Dalam pembangunan daerah ini tentunya harus direncanakan sebelumnya baik perencanaan mengenai waktu pelaksanaan maupun anggaran pembiayaan. Anggaran untuk pembangunan daerah tersebut akan masuk dalam anggaran belanja daerah. Di wilayah Kabupaten Gresik, anggaran pendapatan dan belanja daerah tahun 2018 di atur dalam Peraturan Daerah Kabupaten Gresik No.11 Tahun 2017 tentang Anggaran Pendapatan dan Belanja Daerah Tahun Anggaran 2018. Peraturan daerah ini dibuat dengan menggunakan pedoman Peraturan Menteri Dalam Negeri No.33 Tahun 2017 tentang Pedoman Penyusunan Anggaran Pendapatan Dan Belanja Daerah Tahun Anggaran 2018. Dalam pasal 2 Peraturan Daerah Kabupaten Gresik No.11 Tahun 2017 tentang Anggaran Pendapatan dan Belanja DaerahTahun 2018 disebutkan bahwa salah satu sumber pendapatan daerah berasal dari Pendapatan Asli Daerah. Pendapatan Asli Daerah sebagaimana dimaksud terdiri dari jenis Pendapatan :

a. Pajak Daerah

b. Retribusi Daerah

c. Hasil Pengelolaan Kekayaan Daerah Yang Dipisahkan

d. Lain-Lain Pendapatan Asli Daerah Yang Sah

Kontribusi Pajak Reklame 
Kontribusi adalah iuran atau sumbangan atau sesuatu yang diberikan bersama - sama dengan pihak lain untuk tujuan, biaya atau kerugian tertentu atau bersama. Tingat kontribusi adalah proporsi jenis pajak terhadap total penerimaan pajak baik sebelum dan sesudah pemberlakuan Undang - Undang No 34 Tahun 2000.

Perhitungan kontribusi merupakan salah satu indikator untuk melihat perkembangan pendapatan daerah, proporsi penerimaan pajak, terhadap Pendapatan Asli Daerah. Dengan semakin besarnya proporsi penerimaan pajak dari total pajak atau Pendapatan Asli Daerah, maka semakin layak pajak, sebaliknya semakin kecil proporsi penerimaan maka semakin tidak layak pajak untuk dipungut.

Adapun tarif pajak daerah antara lain sebagi berikut :

\begin{tabular}{|l|c|}
\hline Pajak Daerah Provinsi & $\begin{array}{l}\text { Tarif } \\
\text { Tertinggi }\end{array}$ \\
\hline - Pajak kendaraan \\
bermotor dan \\
kendaraan di atas air \\
- Bea balik nama \\
kendaraan bermotor \\
dan kendaraan di atas \\
air \\
- Pajak bahan bakar \\
kendaraan bermotor \\
- Pajak pengambilan \\
dan pemanfaatan air \\
bawah tanah dan air \\
permukaan
\end{tabular}

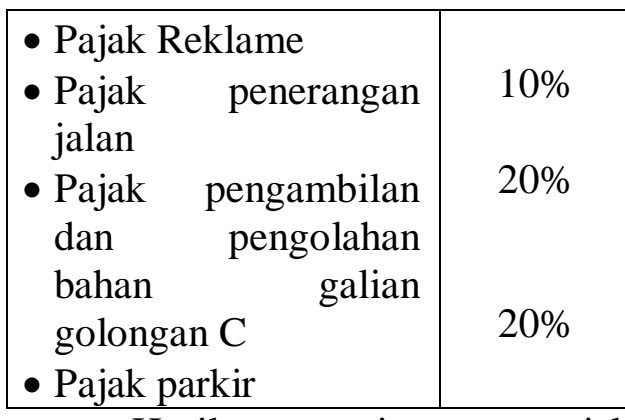

Hasil penerimaan pajak

kabupaten yang diperoleh melalui Pajak Hotel, Pajak Restoran, Pajak Hiburan, Pajak Reklame, Pajak Penerangan Jalan, Pajak Pengambilan Bahan Galian Golongan C, dan Pajak Parkir diperuntukan paling sedikit 10\% (sepuluh persen) bagi desa di wilayah Daerah Kabupaten yang bersangkutan. Bagian yang akan diperoleh oleh desa ditetapkan dengan Peraturan Daerah Kabupaten dengan memperhatikan aspek pemerataan dan potensi antar-desa.

Jika hasil penerimaan pajak kabupaten/kota dalam suatu provinsi terkonsentrasi pada sejumlah kecil daerah kabupaten/kota, Gubernur berwenang merealokasikan hasil penerimaan pajak tersebut kepada daerah kabupaten/kota dalam provinsi yang bersangkutan. Dalam hal objek pajak kabupaten/kota dalam satu provinsi yang bersifat lintas daerah kabupaten/kota, Gubernur memiliki wewenang untuk merealokasikan hasil penerimaan pajak tersebut kepada daerah kabupaten/kota yang terkait. Realokasi yang dilakukan oleh Gubernur atas dasar kesepakatan yang dicapai anar-daerah kabupaten/kota yang terkait dengan persetujuan Dewan Perwakilan Rakyat Daerah Kabupaten/Kota yang bersangkutan. 
Berikut ini data target dan realisasi pajak reklame dari tahun 2016-2018 dan perolehan pajak daerah serta pendapatan asli daerah tahun 2018 yang diperoleh dari DPPKAD Kabupaten Gresik.

\begin{tabular}{|c|l|l|l|}
\hline $\begin{array}{c}\mathrm{N} \\
\mathrm{o}\end{array}$ & $\begin{array}{l}\text { PEMASU } \\
\text { KAN }\end{array}$ & TARGET (Rp) & \multicolumn{1}{|c|}{$\begin{array}{c}\text { REALISASI } \\
(\mathrm{Rp})\end{array}$} \\
\hline 1. & $\begin{array}{l}\text { Pajak } \\
\text { Reklame } \\
\text { Th.2016 }\end{array}$ & $\begin{array}{l}3.205 .800 .000, \\
00\end{array}$ & $\begin{array}{l}3.227 .154 .826 . \\
02\end{array}$ \\
\hline 2. & $\begin{array}{l}\text { Pajak } \\
\text { Reklame } \\
\text { Th.2017 }\end{array}$ & $\begin{array}{l}3.190 .000 .000, \\
00\end{array}$ & $\begin{array}{l}2.850 .763 .697, \\
00\end{array}$ \\
\hline 3. & $\begin{array}{l}\text { Pajak } \\
\text { Reklame } \\
\text { Th.2018 }\end{array}$ & $\begin{array}{l}4.000 .000 .000, \\
\text { 4. }\end{array}$ & $\begin{array}{l}3.381 .700 .015, \\
00\end{array}$ \\
& $\begin{array}{l}\text { Pajak } \\
\text { Daerah } \\
\text { Th.2018 }\end{array}$ & $\begin{array}{l}529.210 .000 .00 \\
0,00\end{array}$ & $\begin{array}{l}578.227 .722 .89 \\
5,46\end{array}$ \\
\hline 5. & $\begin{array}{l}\text { Pendapata } \\
\text { A Asli }\end{array}$ & $\begin{array}{l}2.870 .853 .525 . \\
257,00\end{array}$ & $\begin{array}{l}2.876 .343 .695 . \\
519,71\end{array}$ \\
& $\begin{array}{l}\text { Daerah } \\
\text { Th.2018 }\end{array}$ & & \\
\hline
\end{tabular}

Sumber : DPPKAD Kabupaten Gresik

Untuk mengetahui seberapa besar kontribusi pajak reklame terhadap Pendapatan Asli Daerah (PAD) dapat dilihat melalui kontribusi Pajak Reklame terhadap Pajak Daerah dan Pendapatan Asli Daerah (PAD).

a. Kontribusi Pajak Reklame Terhadap Pajak Daerah.

$\begin{aligned} & \text { Kontribusi Pajak Reklame }= \\ & \text { Penerimaan Pajak Reklame }\end{aligned}$ x100\% Pajak Daerah

Berdasarkan data yang diperoleh dari DPPKAD mengenai pajak tahun 2018 dan dihitung berdasarkan rumus di atas diperoleh hasil kontribusi pajak reklame terhadap pajak daerah sebesar $0.58 \%$. b. Kontribusi Pajak Reklame terhadap Pendapatan Asli Daerah (PAD).

Kontribusi Pajak Reklame $=$

$\frac{\text { Penerimaan Pajak Reklame }}{\text { Pendapatan Asli daerah }} \times 100 \%$

Berdasarkan data yang diperoleh dari DPPKAD mengenai pajak tahun 2018 dan dihitung berdasarkan rumus di atas diperoleh hasil kontribusi pajak reklame terhadap Pendapatan Asli Daerah sebesar $0.12 \%$.

\section{Hierarki Peraturan Perundangan}

Negara Indonesia merupakan Negara Kesatuan yang berbentuk Republik dan merupakan negara hukum. Ini berarti bahwa kedaulatan atau kekuasaan tertinggi dalam negara didasarkan kepada hukum, dalam arti cita hukum (rechtsidee) yang di dalamnya mengandung citacita luhur bangsa Indonesia.

Pasal 1 angka (2) di dalam Bab I Ketentuan Undang-Undang Nomor 12 Tahun 2011 tentang Pembentukan Peraturan Perundangundangan menyebutkan bahwa :

"Peraturan PerundangUndangan adalah peraturan tertulis yang memuat norma hukum yang mengikat secara umum dan dibentuk atau ditetapkan oleh lembaga negara atau pejabat yang berwenang melalui prosedur yang ditetapkan dalam Peraturan Perundang-Undangan."

Dalam membentuk Peraturan Perundang-undangan harus dilakukan berdasarkan pada asas Pembentukan Peraturan Perundang-undangan yang baik, yang meliputi: 
f. kejelasan tujuan;

g. kelembagaan atau pejabat pembentuk yang tepat;

h. kesesuaian antara jenis, hierarki, dan materi muatan;

i. dapat dilaksanakan;

j. kedayagunaan

dan kehasilgunaan;

k. kejelasan

rumusan; danketerbukaan.

Adapun proses pembentukan peraturan perundang-undangan yaitu meliputi :

1. Perencanaan

Perencanaan merupakan tahap awal dalam penyusunan perundang-undangan. Dalam perencanaan diinventarisasi masalah yang ingin diselesaikan beserta latar belakang dan tujuan penyusunan peraturan perundang-undangan. Masalah yang ingin diselesaikan melalui pengkajian dan penyelarasan, dituangkan dalam naskah akademik, kemudian diusulkan untuk dimasukkan ke dalam program penyusunan peraturan. Untuk Undang-Undang, program penyusunannya disebut program legislasi nasional ( Prolegnas ).

m. Penyusunan

Penyusunan
perundang-undangan
diartikan dalam dua maksud
Pertama, penyusunan dalam arti
proses, yakni proses
penyampaian rancangan dari
presiden/gubernur/bupati/wali
kota atau DPR/DPD setelah
melalui tahap perencanaan.
Proses penyusunan ini berbeda
untuk Undang-Undang, peraturan
pemerintah dan peraturan
presiden. Kedua, penyusunan

dalam arti tehkin penyusunan, yakni pengetahuan mengenai tata cara pembuatan judul, pembukaan, batang tubuh, penutup, penjelasan dan lampiran.

n. Pembahasan

Pembahasan

adalah

pembicaraan mengenai substansi peraturan perundang-undangan di antara pihak-pihak terkait. Untuk Undang-Undang, pembahasan dilakukan oleh DPR Bersama presioden atau Menteri melalui tingkat-tingkat pembicaraan. Untuk peraturan dibawahnya, pembahasan dilakukan oleh instansi terkait tanpa keterlibatan DPR.

o. Pengesahan

Untuk Undang-Undang, rancangan Undang-Undang yang telah disetujui Bersama oleh DPR dan presiden disampaikan oleh pimpinan DPR kepada Presiden untuk disahkan menjadi Undang-Undang, disampaikan oleh Menteri Hukum dan HAM kepada Presiden melalui kementerian seketariat negara atau seketariat cabinet.

p. Pengundangan

Tujuan pengundangan
adalah agar $\begin{array}{r}\text { masyarakat } \\ \text { mengetahui isi }\end{array}$ peraturan
perundang-undangan tersebut
dan dapat menjadi acuan kapan
suatu peraturan perundang-
undangan mulai berlaku dan
mengikat.

Sejak lahirnya Negara republik Indonesia dengan proklamasi kemerdekaannya, sampai berlakunya Konstitusi Republik Indonesia Serikat, Undang - Undang Dasar Sementara 1950, Undang - Undang 
Dasar 1945, dan perubahan Undang - Undang Dasar 1945 masalah hierarki perundang - undangan tidak pernah di atur secara tegas.

Di Indonesia, rantai norma hukum ini diaktualisasikan ke dalam hierarki peraturan perundangundangan sebagaimana diatur dalam Undang-Undang Nomor 12 Tahun 2011 tentang Pembentukan Peraturan PerundangUndangan (UU No. 12 Tahun 2011). Pasal 7 ayat (1) UU No. 12 Tahun 2011 menyebutkan mengenai jenis dan hierarki peraturan perundang-undangan di Indonesia, yaitu:

1. Undang-Undang Dasar Negara Republik Indonesia Tahun 1945;

m. Ketetapan Permusyawaran Rakyat;

n. Undang-Undang/Peraturan Pemerintah Pengganti UndangUndang;

o. Peraturan Pemerintah;

p. Peraturan Presiden;

q. Peraturan Daerah Provinsi;

r. Peraturan Daerah Kabupaten/Kota.

Sebagaimana yang telah disebutkan di atas, bahwa peraturan perundang-undangan mengatur pembangunan hukum di Indonesia. Dari hal tersebut dapat dipahami bahwa segala sesuatu yang ada di Negara Indonesia sudah di atur dalam peraturan perundangundangan, termasuk juga mengenai Pemerintahan Daerah serta rancangan pembiayaan dan pendapatan daerah.

\section{Sanksi Tidak Terpenuhinya Pendapatan Asli Daerah dari Pajak Reklame}

Berdasarkan hasil analisis dan hasil lapangan, apabila target dari pajak reklame tidak sesuai dengan realisasi, tidak ada sanksi yang berkaitan dengan hukum. Hanya saja apabila realisasi pendapatan asli daerah tidak memenuhi target, maka insentif tidak akan diberikan kepada pejabat yang berwenang. Karena insentif diberikan apabila Pendapatan Asli Daerah terlaksana sesuai dengan target. Dan hasilnya melampaui target yang sudah ditentukan.

$\begin{array}{ll}\text { Sanksi diberikan } & \text { apabila } \\ \text { terdapat pelanggaran } & \text { terhadap } \\ \text { penyelenggaraan } & \text { reklame. }\end{array}$
Berdasarkan undang-undang yang mendasari penyelenggaraan pajak reklame, terdapat sanksi administrasi dan sanksi hukum. Akan tetapi masing masing memiliki kriteria tersendiri. Berdasarkan Brosur Pajak Reklame yang diperoleh dari DPPKAD Sanksi Administrasi yang akan diberikan meliputi :

q. Kekurangan pajak terutang dikenakan kenaikan $100 \%$ (seratus persen) dari tambahan jumlah pajak apabila ditemukan data baru atau data yang semula belum terungkap.

r. Kekurangan atau keterlambatan pembayaran dikenakan bunga $2 \%$ (dua persen) perbulan dari pokok pajak untuk jangka waktu 24 (dua puluh empat) bulan sejak terutangnya pajak.

s. Tidak menyampaikan SPTPD dalam jangka waktu ditentukan dikenakan bunga 2\% (dua persen) sebulan dari pokok pajak tahun lalu dengan melakukan pemeriksaan lapangan untuk jangka waktu paling lama 24 
(dua puluh empat) bulan sejak saat terutangnya pajak.

t. Kewajiban mengisi SPTPD tidak terpenuhi

u. Pajak yang terutang dihitung secara jabatan.

v. Dikenakan kenaikan $25 \%$ (dua puluh lima persen ) dari pokok pajak ditambah bunga $2 \%$ (dua persen) sebulan dihitung sejak saat terutangnya pajak untuk jangka waktu paling lama 24 (dua puluh empat ) bulan.

Adapun ketentuan pidana adalah sebagai berikut :

a. Wajib pajak yang karena kealpaannya tidak menyampaikan SPTPD atau mengisi dengan tidak benar atau pajak tidak lengkap atau melampirkan keterangan yang tidak benar dapat dipidana dengan pidana denda paling banyak 2 (dua) kali jumlah pajak terhutang yang tidak atau kurang bayar.

b. Wajib pajak dengan sengaja tidak menyampaikan SPTPD atau mengisi dengan tidak benar atau tidak lengkap atau melampirkan keterangan yang tidak benar dapat dipidana dengan pidana penjara paling lama 2 (dua) tahun atau pidana denda paling banyak 4 (empat) kali jumlah pajak terhutang yang tidak atau kurang bayar.

\section{Evaluasi Pencapaian Pajak Reklame}

Pengawasan penyelenggaraan reklame di atur dalam Peraturan Bupati No 9 Tahun 2016 tentang Penyelenggaraan Reklame pasal 36. Pengawasan penyelenggaraan reklame dilakukan oleh Tim Pokja Pengawasan Reklame. Tim Pokja Pengawasan Reklame diketuai oleh Sekretaris Daerah dan dibentuk berdasarkan Keputusan Bupati.

Tim Pokja Pengawasan Reklame sebagaimana dimaksud memiliki tugas untuk melakukan evaluasi dan pengawasan terhadap pelaksanaan penyelenggaraan reklame. Tim Pokja Pengawasan Reklame beranggotakan:

(a) Badan Penanaman Modal dan Perizinan;

Sebagaimana yang telah tertuang dalam Peraturan Bupati Gresik No 9 Tahun 2016 tentang Penyelenggaraan Reklame dalam pasal 37 Badan Penanaman Modal dan Perizinan mempunyai tugas dalam pengawasan sebagai berikut :

1. $\begin{array}{ll} & \text { Izin } \\ \text { Penyelenggaraan } & \text { Reklame }\end{array}$ Insidentil;

2. Penyelenggaraan Reklame Permanen;

3. Izin

PenyelenggaraanReklame Tetap Terbatas;

4.

$$
\text { Izin }
$$

Mendirikan Bangunan (IMB) Reklame.

(b) Dinas Pekerjaan Umum; Dinas Pekerjaan Umum melakukan pengawasan terhadap penyelenggaraan reklame yang memanfaatkan Ruas Milik Jalan serta kesesuaian dan kekuatan konstruksi bangunan reklame yang didirikan. Hal tersebut 
sesuai dengan pasal 39 Peraturan Bupati Gresik No 9 tahun 2016.

(c) DPPKAD;

DPPKAD melakukan pengawasan terhadap perpajakan bagi setiap penyelenggaraan reklame. Sebagaimana yang sudah dijelaskan dalam pasal 38 Peraturan Bupati Gresik No 9 Tahun 2016 tentang penyelenggaraan reklame.

(d) Badan Lingkungan Hidup

Sebagaimana yang telah tertulis dalam pasal 41 Peraturan Bupati Gresik No 9 Tahun 2016 menjelaskan bahwa Badan Lingkungan Hidup melakukan pengawasan terhadap aspek estetika dan keindahan kota serta pengawasan pemanfaatan penempatan reklame di Ruang Terbuka Hijau.

(e) Dinas Perhubungan;

Dinas Perhubungan melakukan pengawasan terhadap keselamatan dan keamanan pengguna jalan.

(f) Dinas Kebudayaan,Pariwisata, Pemuda,dan Olah Raga;

Dinas Kebudayaan,

Pariwisata, Pemuda, dan Olah

Raga melakukan pengawasan terhadap materi reklame yang diselenggarakan.

(g) Satuan Polisi Pamong Praja.

Kantor Satuan Polisi Pamong Praja melakukan pengawasan terhadap ketaatan penyelenggaraan terhadap peraturan perundang-undangan.

Apabila dari hasil pengawasan sebagaimana dimaksud dalam Pasal 36 ditemukan ketidaksesuaian dan/atau penyimpangan terhadap penyelenggaraan reklame, maka masing-masing dinas/instansi terkait, sesuai dengan tugas, pokok, dan fungsinya, membuat laporan tertulis kepada Ketua Pokja Pengawasan Reklame dengan tembusan kepada Instansi terkait.

Berdasarkan data hasil penelitian yang di peroleh dari DPPKAD, pada tahun 2018 realisasi pajak reklame belum mencapai target yang sudah ditentukan. Berdasarkan hasil di lapangan, pengawasan dilakukan untuk melaksanakan control dalam penyelenggaraan dan pencapaian pajak reklame. Pengawasan secara rutin dilakukan setiap 3 bulan/triwulan dan setiap 1 semester (6 bulan). Dan apabila hasil yang diperoleh tidak mencapai target maka dinas terkait akan melakukan evaluasi akhir pada setiap pokja yang terlibat dalam penyelenggaraan reklame.

Dari hasil penelitian di lapangan diperoleh data sebagai berikut:

$$
\begin{aligned}
& \text { DATA HASIL PAJAK } \\
& \text { REKLAME PADA TAHUN } \\
& 2016-2018
\end{aligned}
$$

\begin{tabular}{|c|c|c|c|}
\hline $\begin{array}{l}\mathrm{N} \\
\mathrm{O}\end{array}$ & $\begin{array}{c}\text { PEMAS } \\
\text { UKAN }\end{array}$ & $\begin{array}{l}\text { TARGET } \\
(\mathrm{Rp})\end{array}$ & $\begin{array}{c}\text { REALISAS } \\
\text { I (Rp) }\end{array}$ \\
\hline 1 & $\begin{array}{l}\text { Pajak } \\
\text { Reklame } \\
\text { Th.2016 }\end{array}$ & $\begin{array}{l}3.205 .800 .0 \\
00,00\end{array}$ & $\begin{array}{l}3.227 .154 .8 \\
26.02\end{array}$ \\
\hline 2 & $\begin{array}{l}\text { Pajak } \\
\text { Reklame } \\
\text { Th.2017 }\end{array}$ & $\begin{array}{l}3.190 .000 .0 \\
00,00\end{array}$ & $\begin{array}{l}2.850 .763 .6 \\
97,00\end{array}$ \\
\hline 3 & $\begin{array}{l}\text { Pajak } \\
\text { Reklame } \\
\text { Th.2018 }\end{array}$ & $\begin{array}{l}4.000 .000 .0 \\
00,00\end{array}$ & $\begin{array}{l}3.381 .700 .0 \\
15,00\end{array}$ \\
\hline 4 & $\begin{array}{l}\text { Pajak } \\
\text { Daerah } \\
\text { Th.2018 }\end{array}$ & $\begin{array}{l}529.210 .000 \\
.000,00\end{array}$ & $\begin{array}{l}578.227 .722 \\
.895,46\end{array}$ \\
\hline 5 & $\begin{array}{l}\text { Pendapa } \\
\tan \text { Asli }\end{array}$ & $\begin{array}{l}2.870 .853 .5 \\
25.257,00\end{array}$ & $\begin{array}{l}2.876 .343 .6 \\
95.519,71\end{array}$ \\
\hline
\end{tabular}




\begin{tabular}{|l|l|l|l|}
\hline $\begin{array}{l}\text { Daerah } \\
\text { Th.2018 }\end{array}$ & & \\
\hline \multicolumn{3}{|l|}{ Sumber : DPPKAD }
\end{tabular}

Berdasarkan data yang diperoleh di atas, pada tahun 2017 dan 2018 realisasi pajak reklame tidak sesuai dengan target. Hal tersebut dikarenakan Surat Edaran dari Sekretaris Daerah yang berbunyi:

"Bahwa dalam rangka penataan ruang kota yang terarah dan terkendali, serta untuk mewujudkan penyelenggaraan reklame yang memenuhi aspek etika, estetika, social budaya, ketertiban dan keamanan, Pemerintah Gresik Melarang penempatan semua jenis reklame baik permohonan baru maupun perpanjangan di area rumija dan pulau jalan pada simpang tiga, simpang empat dan simpang lima di wilayah Kecamatan Gresik, Kecamatan Kebomas, Kecamatan Manyar Kabupaten Gresik."

Oleh karena itu pajak reklame pada tahun 2017 dan 2018 mengalami penurunan, dan tidak sesuai dengan target yang sudah ditentukan. Berdasarkan Peraturan Daerah Kabupaten Gresik Nomor 2 tahun 2017 tentang Anggaran Pendapatan Dan Belanja Daerah Tahun Anggaran 2018, pada pasal 1 dan 2 dijelaskan rincian pendapatan yang menjadi target pendapatan daerah. Pada pasal 1 disebutkan Anggaran Pendapatan dan Belanja Daerah Tahun Anggaran 2018 dengan rincian sebagai berikut :

a. Pendapatan Daerah Rp.2.897.503.571.000,00 b. Belanja Daerah

Rp.2.983.138.197.036,00

Defisit

Rp. 85.634.626.036,00

c. Pembiayaan Daerah

1. Penerimaan Pembiayaan Rp. 85.634.626.036,00

2. Pengeluaran Pembiayaan Rp. 0,00

Pembiayaan Netto

Rp. 85.634.626.036,00

Sisa Lebih Pembiayaan Anggaran

Rp. 0,00

Selanjutnya pada pasal 2 disebutkan:

1) Pendapatan Daerah sebagaimana dimaksud dalam Pasal 1 huruf a terdiri dari :

a. Pendapatan Asli Daerah Rp. 947.570.465.000,00

b. Dana Perimbangan

Rp. 1.438.593.338.000,00

c. Lain-Lain Pendapatan Daerah Yang Sah Rp. 511.339.768.000,00

2) Pendapatan Asli Daerah sebagaimana dimaksud pada ayat (1) huruf a terdiri dari jenis Pendapatan :

a. Pajak Daerah Rp. 517.050.000.000,00

b. Retribusi Daerah

Rp. 126.010.881.000,00

c. Hasil Pengelolaan Kekayaan Daerah Yang Dipisahkan Rp.13.157.353.000,00

d. Lain-Lain Pendapatan Asli Daerah Yang Sah Rp. 291.352.231.000,00

3) Dana Perimbangan sebagaimana dimaksud pada ayat (1) huruf $\mathrm{b}$ terdiri dari jenis Pendapatan :

a. Dana Bagi Hasil Pajak/Hasil Bukan Pajak Rp. 177.133.682.000,00 
b. Dana Alokasi Umum

Rp. 909.888.092.000,00

c. Dana Alokasi Khusus

Rp. 351.571.564.000,00

4) Lain-Lain Pendapatan Daerah Yang Sah sebagaimana dimaksud pada ayat (1) huruf c terdiri dari jenis Pendapatan :
a. Hibah
Rp. 0,00
b. Dana Darurat
Rp. 0,00
c. Dana Bagi Hasil Pajak dari Provinsi
Rp. 214.548.840.000,00
d. Dana Penyesuaian dan
Otonomi Khusus
Rp. 280.565.128.000,00
e. Bantuan Keuangan dari Provinsi atau Pemerintah Daerah Lainnya.
Rp. 16.225.800.000,00

Berdasarkan Rancangan anggaran yang disebutkan dalam Peraturan Daerah Kabupaten Gresik Nomor 2 tahun 2017 tentang Anggaran Pendapatan Dan Belanja Daerah Tahun anggaran 2018, rancangan pendapatan daerah yang berasal dari pendapatan asli daerah di tetapkan sebesar Rp.947.570.465.000,00. Sedangkan dalam realisasi pelaksanaannya, Pendapatan Asli Daerah pada tahun 2018 berdasarkan data yang di peroleh dari DPPKAD didapatkan sebesar Rp. 2.876.343.695.519,71. Dari data tersebut dapat dilihat bahwa perolehan dana Pendapatan Asli Daerah melebihi dana yang sudah disebutkan dalam anggaran sehingga dapat disimpulkan bahwa perolehan dana dari pajak reklame tidak sepenuhnya mempengaruhi perolehan Pendapatan Asli Daerah.

\section{SIMPULAN}

Berdasarkan Peraturan Bupati Gresik Nomor 9 Tahun 2016 tentang penyelenggaraan reklame dan berdasarkan data tentang pajak reklame dan pajak daerah diperoleh dari DPPKAD, hasil kontribusi pajak reklame terhadap pajak daerah sebesar $0.58 \%$ dan kontribusi pajak reklame terhadap Pendapatan Asli Daeah sebesar $0.11 \%$. Pada tahun 2017 dan 2018 realisasi pajak reklame tidak sesuai target dikarenakan banyak factor. Salah satunya terkait edaran dari Sekretaris Daerah Kabupaten Gresik. Dan evaluasi dilakukan pihak terkait setiap 3 bulan (triwulan) dan setiap 6 bulan ( 1 semester ) disetiap pokja yang terkait dengan penyelenggaraan reklame.

\section{DAFTAR BACAAN}

\section{Buku - Buku}

Bohari. Pengantar Hukum Pajak. PT. Raja Grafindo Persada, Jakarta 2002

Indrati,Maria Farida. Ilmu Prundangundangan (Jenis, Fungsi Dan Materi Muatan). Kanisius. 1996.Yogyakarta

Kamus Pusat Bahasa, Kamus Bahasa Indonesia. Departemen Pendidikan Nasional, Jakarta 2008

Marihot P Siahaan. Pajak Daerah dan Retribusi Daerah. PT. Raja Grafindo, Jakarta 2006

Marzuki, Peter Mahmud. Penelitian Hukum. Kencana, Jakarta, 2005

Moleong, Lexy J. Metodologi Penelitian Kualitatif. Bandung : 
PT Remaja Rosdakarya,

Bandung, 2011

Soemitro, Rochmat. Pengantar

Singkat Hukum Pajak . PT.

Eresco Bandung, 1992

Suandy, Erly. Hukum Pajak.

Salemba Empat. Jakarta. 2013

Sutedi, Adrian. Hukum Pajak. Sinar

Grafika. Jakarta. 2016

Syofyan, Syofrin dan Asyhar Hidayat. Hukum Pajak dan Permasalahannya. PT.Refika Aditama, Bandung, 2004

\section{Karya Ilmiah}

Haris, Andi. Implementasi Peraturan

Daerah Nomor 2 Tahun 2012

Tentang Pajak Reklame (

Studi Kasus Dinas

Pengelolaan Keuangan

Daerah Kabupaten

Bulukumba Tahun 2012 S/D

2015). Skripsi, Fakultas

Hukum, Universitas Islam

Negeri Alauddin Makassar. 2016.

Hatmadi, Widyo. Pelaksanaan Peraturan Daerah

Kabupaten Sukoharjo Nomor 12 Tahun 2003 Tentang Pajak Reklame Dalam Meningkatkan Pendapatan Asli Daerah ( Studi Kasus Di Bpkd Kabupaten Sukoharjo ). Skripsi, Fakultas Ilmu Sosial dan Ilmu Politik, Universitas Indonesia. 2012.

\section{Media Online}

Kabupaten Gresik, Wikipedia ( Online ), 15 November 2018, h 1 https://id.wikipedia.org/wiki/Kab upten_Gresik

http://setkab.go.id/apa-yang-perludiketahui-untuk-membuatperaturan-perundang-undangan/ $10 / 07 / 1919.30$

\section{Peraturan Perundang - Undangan}

Peraturan Bupati Gresik Nomor 9 Tahun 2016 tentang Penyelenggaraan Reklame

Undang - Undang Dasar Negara Republik Indonesia Tahun 1945

Undang - Undang Nomor 12 Tahun 2011 tentag Pembentukan Peraturan Perundang - Undangan

Undang - Undang Nomor 23 Tahun 2004 tentang Pemerintah Daerah

Undang - Undang Nomor 28 Tahun 2009 tentang Pajak Daerah dan Retribusi Daerah

Peraturan Daerah Kabupaten Gresik Nomor 11 Tahun 2017 Tentang Anggaran Pendapatan Dan Belanja Daerah Tahun Anggaran 2018 